\title{
MOLINIST GUNSLINGERS REDUX: A FRIENDLY RESPONSE TO GREG WELTY
}

\author{
KENNETH D. KEATHLEY*
}

Southeastern Baptist Theological Seminary

\begin{abstract}
Philosopher Greg Welty contributed a chapter entitled 'Molinist Gunslingers: God and the Authorship of Sin', to a book devoted to answering the charge that Calvinism makes God the author of sin (Calvinism and the Problem of Evil). Welty argues that Molinism has the same problems as Calvinism concerning God's relationship to sin, regardless of what view of human freedom Molinism may affirm. The Molinist believes that God generally uses his knowledge of the possible choices of libertarianly free creatures in order to accomplish his will. (This knowledge is typically categorized as residing within God's middle knowledge.) But affirming libertarian freedom for humans, he argues, does not help in dealing with the question of God's relationship to evil. Therefore, Molinism is no better than Calvinism, at least concerning this issue. In response to Welty, (1) I agree with him that Molinism does not have a moral advantage over what he calls 'mysterian, apophatic' Calvinism, but Molinists don't claim that it does, and (2) I argue that, contra Welty, Molinism indeed does have a moral advantage over the Calvinist versions that do employ causal determinism. Welty does not take 'intentions' into consideration in his argument, and this is a serious flaw. In the libertarian model of Molinism, intent originates in the doer of evil. However, in the compatibilist model of causal determinism, ultimately God implants intent. Thus, adherents of causal determinism have difficulty not laying responsibility at the feet of God.
\end{abstract}

KEY WORDS: Molinism, Calvinism, determinism, libertarianism, problem of evil

Recently philosopher Greg Welty (2016) contributed a chapter entitled 'Molinist Gunslingers: God and the Authorship of Sin', to a book devoted to answering the charge that Calvinism indeed makes God the author of sin. [I first engaged Greg's work when he presented it as a paper at an Evangelical Theological Society meeting in 2011, and it is primarily with that paper this work interacts.] Many across the theological spectrum have raised this concern, but Welty specifically addresses the objections raised by Molinists. The

KENNETH D. KEATHLEY (PhD 2000, Southeastern Baptist Theological Seminary) is Senior Professor of Theology occupying the Jesse Hendley Chair of Theology and directs the L. Russ Bush Center for Faith and Culture at Southeastern Baptist Theological Seminary. Email: kkeathley@sebts.edu. 
title, 'Molinist Gunslingers', comes from a clever illustration he presents based on the 'Bullet Bill' character from the Mario Brothers video games. I will discuss his illustration later in the essay.

Welty's main thesis appears to be thus: Molinism, with its belief that God perfectly accomplishes his will primarily by means of his exhaustive foreknowledge, has the same problems as Calvinism concerning God's relationship to sin, regardless of what view of human freedom Molinism may affirm. The Molinist believes that God generally uses his knowledge of the possible choices of significantly free creatures in order to accomplish his will. (This knowledge is typically categorized as residing within God's middle knowledge.) But affirming libertarian freedom for humans, he argues, does not help in dealing with the question of God's relationship to evil. Therefore, Molinism is no better than Calvinism, at least concerning this issue.

Greg Welty and I are good friends and colleagues. Both of us teach at Southeastern Baptist Theological Seminary in Wake Forest, North Carolina. We have lunch together. In the times we have discussed and debated these issues he has always demonstrated grace and patience. Greg is also one of the smartest fellows I know. Therefore, I take his objections seriously.

In response to Welty's claims concerning the matter of God's relationship to sin, (1) I agree with him that Molinism does not have a moral advantage over what he calls 'mysterian, apophatic' Calvinism, but Molinists don't claim that it does, and (2) I argue that, contra Welty, Molinism indeed does have a moral advantage over the versions of Calvinism that do employ causal determinism.

\section{Welty's Molinist Gunslingers Summarized}

Welty makes two arguments: (1) Molinists overgeneralize when they characterize Calvinism, and (2) even if they were correct in their characterization, their position does not enjoy the advantage they believe it does.

\section{Welty's First Argument: Molinists Overgeneralize in}

\section{Their Characterization of Calvinism}

Welty begins his answer to the claim 'Calvinism makes God the author of sin whereas Molinism does not' by surveying what he calls the 'standard Calvinist replies' (Welty 2016: 56). He notes that Jonathan Edwards distinguished between two senses of 'cause'. God is not the cause of sin in the sense of being 'the sinner, the agent, or actor of Sin, or the doer of a wicked thing', but he is the cause of sin in the sense that God 'ordains that moral evil shall in fact occur' (Edwards 1957a: 399; cf. Welty 2016: 57). So, to employ the standard Aristotelian categories, God is not the efficient cause of sin, but his plan and his purpose are the formal and final causes of evil. I would simply say at this point that these distinctions historically have been acknowledged 
by all orthodox Christians, including Molinists, so there is nothing distinctively Calvinist about this explanation, as expressed.

However, laments Welty, 'this distinction is not going to do it for the Molinist critic of Calvinism', and he notes that Molinists, just as Calvinists, affirm that 'God ordains whatsoever comes to pass, and this includes ordaining that acts of moral evil come to pass' (Welty 2016: 57). [He cites my use of the language of permission to describe the relationship of God's eternal decree to moral evil (Keathley 2010: 139). I also argue that Molinism has a more accurate and robust understanding of the concept of permission. Many Calvinists use 'permission' in a way that turns the meaning on its head. For example, Paul Helm states, 'Permission' in the case of God is every bit as much an action as is sperformance’' (Helm 1994: 101). This seems to me to be a very unhelpful way of putting things. In Molinism, permit means 'to allow', which is the Webster's Dictionary definition.] He continues:

What bothers the Molinist is that, on Calvinism, God seems to be the sufficient cause for various acts of sin that occur in his universe, and this means that God is responsible-morally responsible-for every sin that occurs... In short, the Molinist will insist that the way that God ordains sin on Calvinism is by way of causal determinism, which implies that God is the sufficient cause of sin, which implies that God is a sinner, with all the responsibility and culpability that that entails (Welty 2016: 57).

Welty suggests that, on this matter, Molinists may be making two mistakes: imputing to Calvinism an adherence to causal determinism, and failing to recognize that Molinism is 'sufficiently analogous' to Calvinism with regard to imputing responsibility to God. Fleshing out responses to these two perceived mistakes constitutes the bulk of Welty's two arguments.

Molinists fail to notice, contends Welty, that when it comes to understanding exactly how the divine decree is efficacious, Calvinists typically take an apophatic approach (Welty 2016: 57). [Apophatic theology is to speak by way of negation (via negativa). If we are not able to explain what something is, we can attempt to describe it by saying what it is not.] He points to the Westminster Confession of Faith and the significant role it has played in the thinking of Reformed theologians such as B. B. Warfield and Paul Helm. In the words of Westminster, 'God from all eternity, did, by the most wise and holy counsel of His own will, freely, and unchangeably ordain whatsoever comes to pass; yet so, as thereby neither is God the author of sin, nor is violence offered to the will of the creatures; nor is the liberty or contingency of second causes taken away, but rather established' (3.1). Welty argues that the wording is reminiscent to that of the Chalcedonian Definition concerning the hypostatic union of Christ: 
There is no explanation of how the positive claim can be true in light of the negative claims; no detailed model or mechanism is provided that would illuminate for us their interrelations...Given this apophatic definition of the decree, the authors leave it a mystery why (for instance) if God ordains everything that comes to pass, and if human sin comes to pass, why it is that God is not responsible or culpable for those sins (Welty 2016: 58).

At this point, Welty admits that some Calvinists do indeed embrace causal determinism, but he distances himself from them. He contends that there is a difference between 'apophatic, mysterian' Calvinists and creative, 'industrious' Calvinists. He states, 'It is important not to lump all Calvinists into the same category. There are the «mysterian`Calvinists who rest content with apophatic formulations, in the grand historical tradition of Chalcedon. It is not clear they make God the author of sin in any objectionable sense' (Welty 2016: 59). These are to be contrasted from their adventuresome, speculative brethren: 'And then there are the «creative> Calvinists (the industrious Calvinists?) who supplement or fill out the confession's teaching on the decree with the thesis of universal causal determinism, and perhaps even occasionalism. If they are subject to critique, so be it' (Welty 2016: 59). So Welty is willing to throw his deterministic Calvinist brethren under the bus while admonishing Molinists to distinguish between the two: 'but we need to be clear just who is saying what, rather than claiming that Calvinists-as a group-eschew mystery and apophasis in favor of causal determinism, divine causal sufficiency, and so on' (Welty 2016: 59).

Welty does not say whether or not this apophatic approach embraces or allows for a libertarian view of human agency. He seems to leave this as an open question. Perhaps he believes that such an approach does not have to commit to any model of human agency. However, many would argue that, in regard to human choice, determinism and libertarianism are the only two options. If the conceptual space is exhausted by these two options, and one wishes to reject determinism, isn't one left with libertarianism?

Welty's Second Argument: Molinism Possesses No Superiority over

Calvinism concerning the Problem of Evil

Welty then moves to his second argument, which is the main point he seems really to want to make. He claims that, even if everything he wrote so far turned out to be incorrect, Molinism would still not be (morally) superior to Calvinism, because it is 'sufficiently analogous' to Calvinism. 'If divine causation in Molinist providence is sufficiently analogous to sufficient causation, then Molinism inherits all of the Calvinist liabilities anyway, with respect to divine authorship of sin, responsibility, and blame' (Welty 2016: 60). To make his case, Welty presents an entertaining thought experiment using 
characters from the classic Mario Brothers video games. He compares a murder committed with an ordinary gun to a murder committed using a gun in which the bullets possess libertarian free will-an ordinary gun versus a 'Bullet Bill' gun.

First, he asks us to consider a murder committed with an ordinary gun. Using an ordinary gun, the killer actualizes the circumstances, but the act of pulling the trigger is not sufficient by itself. He is relying on the laws of nature to finish the job. Moreover, these laws are contingent (because they could have been different) and prevolitional (at least from the perspective of the shooter). Yet, the killer's responsibility would be universally recognized.

Now consider a murder perpetrated with a Bullet Bill gun. The bullet in this case would be the Mario Brothers character-a black bullet with the evil grin. Welty supposes, for the sake of his argument, that Bullet Bill possesses libertarian free will. Even though Bullet Bill freely chooses to kill the targeted victim, the one wielding the gun also is culpable. Welty then applies the Bullet Bill scenario to Molinism. The person firing the gun has counterfactual knowledge of what Bullet Bill will do. And the person pulling the trigger is aiming at the victim. 'On Molinism, God actualizes circumstances in which he knows (say) that an assassin will take out a number of targets' (Welty 2016: 64). Though the circumstances by themselves are not sufficient to cause the murder, though God is using truths that were prevolitional to him, and though the assassin possesses libertarian freedom, God 'is responsible for what the assassin will in fact do' (Welty 2016: 67).

Welty concludes that Molinists, for all our care to maintain libertarian freedom for humans and hence assign moral responsibility to them, have failed to realize that our model makes God the author of sin just as much as deterministic Calvinism. He writes: 'It seems to me that Molinists have studiously focused on articulating a model in which the human agent remains responsible in a strong libertarian sense, but have not sufficiently attended to the fact that their model nevertheless makes God the author of sin and responsible for the fact that sin comes to pass. These latter questions do not go away simply in virtue of preserving human libertarian free will' (Welty 2016: 68).

\section{My Response to Welty's Molinist Gunslingers}

It should be noted that Welty addresses a significant claim of Molinism, but not Molinism's central or primary claim. Initially, in response to the historical challenge of fatalism as espoused by the Greek Stoics and later by Islam, the primary concern of Molinism was to establish the contingency of future conditionals in the light of God's exhaustive foreknowledge (Craig 1988). Later, determinism of the Hobbesian variety became a challenge when Jonathan Edwards incorporated Thomas Hobbes's views into his theology of 
providence (Guelzo 1989). [ The debate continues about how much Edwards incorporated Hobbes's views into his theology of providence.] As many Calvinists followed Edwards in embracing determinism (particularly in America), proponents of Molinism argued that their model enjoyed the advantages that Welty is challenging. So even if Welty's critique is correct, he has not addressed the central concern of Molinism. But I do not think his critique is correct.

\section{Response to Welty's First Argument that Molinists Overgeneralize in Their Characterization of Calvinism}

Do Molinists overgeneralize in their depiction of Calvinism? And more to the point—does Molinism enjoy a moral advantage over 'mysterian, apophatic' Calvinism specifically concerning God's relationship to sin? The short answers are no and no, at least not compared to the type of 'apophatic Calvinism' Welty defines in his paper.

In fact, Welty's complaint seems to overgeneralize about Molinists. He states, 'By imputing to Calvinists the thesis that God governs his universe by way of strict causal determinism, Molinists may be overlooking the apophatic character of Reformed definitions of divine providence, as these are enshrined in historically Reformed confessions of faith' (Welty 2016: 57). Regarding his claim that Molinists overgeneralize in their characterization of Calvinism, I wish to respond with four points.

First, I don't believe I made that mistake in Salvation and Sovereignty (my book is the only Molinist work he cites). To the contrary, I specifically quote Calvinists who are critics of causal determinism (Keathley 2010: 97-99). The book notes in a number of places that on this issue there are different streams of thought within Calvinism.

Second, I distinguished between those causal determinists who acknowledge its problems from those who do not. As an example to illustrate the difference between the two, I compared and contrasted the approach of R. C. Sproul Sr with that of his son, R. C. Sproul Jr (Keathley 2010: 80-86). Both affirm determinism, but they come to very different conclusions concerning how and why Adam and Eve chose to sin. Sproul Sr. takes the mysterian approach advocated by Welty: 'In spite of this excruciating problem we still must affirm that God is not the author of sin... One thing is absolutely unthinkable, that God could be the author or doer of sin' (Sproul Sr 1986: 31). Sproul Jr, by contrast, rushes in where his father has feared to tread. He contends that God directly changed Eve's inclinations from good to evil. In this way, God introduced evil into the world; he is 'the culprit' (Sproul Jr's term). 'Of course, it is impossible for God to do evil. He can't sin', reasons Sproul Jr, 'This objection, however, is off the mark. I am not accusing God of sinning; I am suggesting that he created sin' (Sproul Jr 
1999: 54). I took pains to point out that most Calvinists have not followed the approach taken by Sproul Jr (Keathley 2010: 85, 89, 96, 98). [Welty's statement quoted earlier, 'this distinction (i.e., between apophatic Calvinism and deterministic Calvinism) is not going to do it for the Molinist critic of Calvinism', is confusing. I am the only Molinist he cites, so I have to assume he is referring to me. But I make clear that my complaint is with causal determinism. Also, there are more Reformed adherents of causal determinism than he seems to want to admit. For example, John Feinberg argues, 'So, an act is free, though causally determined, if it is what the agent wanted to do' (Feinberg 2001: 637).] Thus, Welty's objection on this point seems to be off the mark.

Third, I also make a point of noting, in regards to God's eternal decree, there is little difference between Molinism and infralapsarian Calvinism, particularly in a section entitled, appropriately enough, 'The Similarities of Infralapsarian Calvinism and Molinism' (Keathley 2010: 140-142). In fact, Molinism, with its more robust definition of 'permission', may be simply a more consistent version of infralapsarianism. This is why many Arminians reject Molinism (Olson 2006: 194-199; Picirilli 2002: 62-63). Molinists have long recognized the similarities on this point, as can be seen by the titles to certain articles written by significant Molinists, e.g., 'Is Molinism as Bad as Calvinism?' (Walls 1990) and 'Is Molinism as Depressing as Calvinism?' (Craig 2017).

Fourth, Molinists have no real problem with what Welty calls 'the standard Calvinist replies'. We just don't think Calvinists are consistent in this area. For example, Molinists affirm, along with Edwards, the distinction between efficient causation and formal or final causation. (Unfortunately, Edwards was not consistent on this point, as we will see shortly.) Molinists like 3.1 of the Westminster Confession, with its affirmation, 'God from all eternity, did, by the most wise and holy counsel of His own will, freely, and unchangeably ordain whatsoever comes to pass' and its cautious qualification that 'yet so, as thereby neither is God the author of sin, nor is violence offered to the will of the creatures', and when it concludes that 'nor is the liberty or contingency of second causes taken away, but rather established'. In fact, Molinists believe we have fewer difficulties with the statement than do many of our Calvinist brethren. Concerning 3.1, William Lane Craig declares,

Now this is precisely what the Molinist believes! The Confession affirms God's preordination of everything that comes to pass as well as the liberty and contingency of the creaturely will, so that God is not the author of sin. It is a tragedy that in rejecting middle knowledge Reformed divines have cut themselves off from the most perspicuous explanation of the coherence of this wonderful confession (Craig 2010). 
Welty and I both have signed the Abstract of Principles, which is one of the doctrinal statements (along with the Baptist Faith and Message 2000) guiding Southeastern Seminary. Most recognize the Abstract to be a fairly Calvinistic document. The pertinent passage is Article 4: 'God from eternity decrees or permits all things that come to pass and perpetually upholds, directs and governs all creatures and all events; yet so as not in any wise to be author or approver of sin nor to destroy the free will and responsibility of intelligent creatures'. As a Molinist, I can affirm this article wholeheartedly without holding to a counterintuitive definition of free will.

\section{Response to Welty's Second Argument that Molinism, Morally Speaking, Is 'Sufficiently Analogous' to the Type of Calvinism That Embraces Causal Determinism}

Welty's second argument is the main claim of his chapter, and it is to this point he gives the most attention. He states,

Let's assume that everything I just said is wrong. Let's assume for the sake of argument that Molinists are right in their views of what Calvinists must believe if their characteristic claims about divine providence (both positive and negative) are to 'make sense'. Let's say that Calvinism must make God the sufficient cause of sin, and so its author in an objectionable sense... Thus, given our ordinary intuitions about cases involving sufficient causation and moral responsibility, Molinism makes God the author of sin (in the objectionable sense) if Calvinism does (Welty 2016: 60).

My short answer to his second claim is that I do not think Welty has made his case. And it seems that his argument, if successful, would succeed too well. All theological systems that uphold the traditional view of God's omniscience would be open to this charge (Welty may contend that that's exactly his point). But what does this say about the efforts of apophatic Calvinists to distance themselves from the implications of causal determinism? Most Calvinists distinguish between primary and secondary causation, and embrace infralapsarianism over supralapsarianism. This is why Welty takes an apophatic approach while leaving determinists to fend for themselves. ('If they are subject to critique, so be it.') Many of our Reformed brethren recognize the moral difficulties posed by an adherence to causal determinism.

Welty argues that 'mysterian, apophatic' Calvinists avoid philosophical speculations, reject causal determinism, and also reject occasionalism (i.e., the view that each moment is the discrete, direct creation of God, and hence he is the actual, sole cause of all events).

Then, remarkably, Welty presents Jonathan Edwards as an example of an apophatic theologian. But most Edwardsian scholars consider Edwards 
to have been brilliantly speculative, and many also credit Edwards with incorporating causal determinism (and occasionalism!) into modern Calvinism. Edwards may have affirmed, in places, that God was not the doer or author of sin, but at other places he was not consistent with that affirmation. In Freedom of the Will, Edwards argues that Adam fell because God created within him the necessary imperfections to guarantee the Fall. He declares, 'If $\sin$ had not arose from the imperfection of the creature, it would not have been so visible, that it did not arise from God, as the positive cause, and real source of it-but it would require room that cannot be here allowed fully to consider all the difficulties which have been started, concerning the first entrance of sin into the world' (Edwards 1957a: 413). The comments on this passage by Calvinist and Edwardsian theologian, John Gertsner, are sufficient:

When I read this paragraph many years ago, it froze my blood. I could not believe it; that is, I could not believe that Edwards meant it or thought of its implications. By now I have come to the sad but inescapable conclusion that he knew what he was writing and meant it as stated. This I conclude although I do not believe that Edwards ever recognized that this doctrine implies the purest conceivable form of fatalism, and a total abandonment of the Christian religion, as understood by almost the entire catholic tradition, including himself, through all the ages of the Church's history, and in all the pages of Edwards' most biblically oriented writing! (Gertsner 1992: 321-322)

In Original Sin, Edwards (1957b: 389-413) clearly argues for occasionalism. Paul Helm (a Calvinist) gives his curt assessment: 'This is, of course, a preposterous view, for all sorts of reasons. But the chief reason, for our purposes, that it must be emphatically rejected is that there is no place in it for horizontal causation' (Helm 1994: 86). [However, John Piper (1998: 95-96) endorses Edwards's occasionalism.] Edwards saw God's will as the sole, efficient cause of all things, including sin. Thus, I am not sure why Welty presents him as a mysterian, apophatic Calvinist.

I do not believe one can hold that God accomplishes his will via causal determinism and then appeal to mystery. Where, exactly, is mystery to be located? There seem to be three options. One place possibly could be the question as to why God created this particular world knowing that evil would occur. To my knowledge, both Molinists and Calvinists confess this type of mystery. There's no dispute here. A second possible location could be the mystery of how God accomplishes his will through other causal agents. Molinists contend that God, with precision and success, perfectly accomplishes his will through genuinely free creatures primarily by means of his omniscience. If, concerning God's concurrent actions with other agents, apophatic Calvinists wish to appeal to mystery on this point, then this would not seem necessarily to be 
an item of conflict between Molinists and Calvinists. Molinists provide a possible model while apophatic Calvinists do not, but both affirm that God can and does perfectly accomplish his will. Again, this creates no problem between apophatic Calvinists and Molinists.

If the above two locations of mystery are where Calvinists refer to when they speak of mystery, then we are in agreement. However, I fear many Calvinists locate mystery in a third place: why God is not culpable for the evil actions he causally determined. This is problematic. Apophatic, mysterian language does not work at this point. It's one thing to say that it is a mystery how God concurrently accomplishes his will through other agents. It's another thing to say that it's a mystery as to why he is not accountable when he causally determines their sins. If this is what is meant when Calvinists appeal to mystery, then indeed Molinists and Calvinists are at odds at this point. Calvinist theologian R. K. McGregor Wright solves this dilemma by arguing that God is not accountable simply because he has no one to whom he must give an account (McGregor Wright 1996: 177-204). Such an argument seems to concede the charge that Calvinism makes God the author of sin.

Many Calvinists, I am happy to note, do not agree with McGregor Wright's conclusions. Generally, at this point, they appeal to the concept of permission. Calvinist Bruce Ware states, 'It seems to me, that the strain in Calvinism that has been reluctant to embrace the permissive will of God simply rejects one of the very conceptual tools necessary to account for God's moral innocence in regard to evil. Surely more is needed than just this manner of divine activity. But I don't see how we can proceed if God's sovereign dealings in matters of good and evil are, in fact, symmetrical' (Ware 2004: 26).

Like Ware, Welty has good reason to distance himself from causal determinism, but in so doing he is disagreeing with a significant portion of modern Calvinists. However, I don't think his argument is successful, primarily because it does not address the important issue of intent.

\section{The Crucial Issue of the Origin of Intentions}

The origin of intent matters, and so do the differences in intent. I'm glad that Welty notes that his argument is based on 'our ordinary intuitions' about moral culpability, because our intuitions about intent play a role in our understanding of responsibility.

Consider the legal distinction between a sting operation and entrapment. The judicial system distinguishes between the two, and the origin of the intent provides the crucial ethical distinction. What incurs culpability for the suspect is the origin of the intent within the suspect to commit the crime. As long as the intent to commit the crime originated in the mind of 
the criminal, and the police merely facilitate the crime (or feign facilitating the crime via a sting operation), then no entrapment has occurred. This distinction employs 'our ordinary intuitions'.

In this regard, the differences between libertarianism and determinism (i.e., compatibilism) really do matter. The distinctive feature of libertarianism, as advocated by proponents such as J. P. Moreland (2002: 141), is agent causation ('the notion of an active power'). We are created beings, so whatever freedom we have is not autonomous. But we are created in the divine image, so we reflect God's ability to make moral choices. This ability is limited and derived, but real. Robert Saucy says that this power constitutes what might be termed 'a little citadel of creativity ex nihilo' (Saucy 1993: 38).

So also in the libertarian model of Molinism, intent originates in the doer of evil. However, in the compatibilist model of causal determinism, ultimately God implants intent. Like law enforcement officials who implant the intent within the suspect (and thus are guilty of entrapment), adherents of causal determinism have difficulty not laying responsibility at the feet of God. Determinists such as Edwards, Sproul Jr., and McGregor Wright illustrate this.

\section{What Is the Difference in Intent in Welty's Thought Experiment?}

In the example of the two shooters, are they 'sufficiently analogous' so that the one using Bullet Bill is just as morally culpable as the first shooter? I think most would agree that the answer is yes. But I don't think his example applies to Molinism. First, it is doubtful this one example should be extrapolated to apply to all relevant scenarios, and second (and more importantly), this example does not seem to apply to any scenario posited by Molinists.

The question at hand concerns moral culpability. In Welty's example, the intent of both shooters (it appears) is to commit murder. The fact that the second shooter used a gun containing a bullet possessing libertarian freedom (Bullet Bill) absolves him of nothing. We all agree that the man who hires a hit man is also guilty of the hit man's crime.

God indeed works through the evil done by wicked agents (Genesis 50; Isaiah 10; Acts 2). All Christians affirm this. But it really does matter whether or not those agents were the origins of their respective choices, and that at significant points they possessed the genuine ability to make those choices. For the Molinist, God does not have the intention, 'I am creating Bullet Bill merely in order that he commit the murder I know that he will freely commit'.

\section{Examples where Intentions Matter}

In moral arguments, intentions matter. Even a strongly Reformed voice such as Paul Helm emphasizes this: 'In the case of evil, whatever the diffi- 
culties may be of accounting for the fact, God ordains evil but he does not intend evil as evil, as the human agent intends it... There are other ends or purposes which God has in view' (Helm 1994: 190). God's intentions and purposes are different from the evil intentions and purposes of the wicked through whom he works or of those he permits to do evil. Molinism understands these evil persons to be the causal agents of their deeds. Thus, Molinism is not 'sufficiently analogous' to those versions of Calvinism that affirm causal determinism. Examples:

God can permit or allow an evil for just reasons. Consider the following analogy. During World War II, the Allies broke the secret codes of the Germans. According to some historians, the British knew beforehand of German plans to carpet bomb the city of Coventry. It was determined that if special actions were taken to defend the city, then that would tip off the Nazis that the Allies were intercepting their messages. Churchill reportedly made the difficult decision to allow the bombing to occur. Most would agree that Churchill's responsibility is not 'sufficiently analogous' to that of the Axis forces. Similarly, God permits evil but is not culpable for it.

God can accomplish righteous purposes through agents that have evil intentions. Again, consider the following analogy. Imagine the execution of a heinous criminal. Imagine also that the executioner carrying out the death sentence secretly delights in killing other humans, and he enjoys legally performing an act that otherwise would be considered murder. The executioner's evil intent does not impugn the state's just cause. The intent of both is not 'sufficiently analogous'. Similarly, God uses evil people, but he is not culpable for their evil deeds.

\section{The Difficulty of Assigning Moral Responsibility in a Causally Determined Universe}

Those of us opposed to causal determinism are not simply shadow boxing. The challenges posed by determinism to morality become very clear in the writings of Darwinists. For example, in his The Moral Animal: The New Science of Evolutionary Psychology, Robert Wright (a former Southern Baptist) argues for genetic causal determinism. He does not hesitate to describe humans as 'puppets' and 'robots'. He disposes of notions such as free will and moral responsibility. Evil does not exist. He laments that humans are 'robots' held 'responsible for their malfunctions' (Wright 1994: 355). The primary advocates of determinism are not Calvinists, but atheists and Muslims.

I rejoice that mysterian Calvinists such as Welty also reject causal determinism. It may have been helpful if Welty had spelled out clearly what models of human agency he believes to be compatible with apophatic Calvinism. Does he believe that libertarian freedom is a live option for the 
apophatic Calvinist? He doesn't say. The mysterian Calvinist seems to be noncommittal on whether or not God causes sin. If God causally determines sins, then the Calvinist position is indeed more problematic than the Molinist position, regardless of a claim to mystery. And it seems that if one denies that God causally determines sinful actions, then one needs Molinism to get the robust sense of God's sovereign control of all things. For the Christian, the options are divine determinism (either of an occasionalist variety or of an Edwardsian strongest desire variety) or (some form of) libertarianism. What other option is there?

For the reasons given above, Molinists believe that preserving libertarian freedom makes a significant difference in distinguishing between the just and pure decisions by God either to permit or work through the wicked and impure actions of humans. According to determinism, humans are not agents but rather are mere instruments. The Molinist believes that persons are causes, and for this reason they can be and, in fact, are morally responsible creatures.

\section{Bibliography}

Craig WL (1988) The Problem of Divine Foreknowledge and Future Contingents from Aristotle to Suarez. Leiden: Brill.

Craig WL (2010) Molinism vs. Calvinism. Available from: http://www.reasonablefaith.org/molinism-vs-calvinism.

Craig WL (2017) Is Molinism as Depressing as Calvinism? Available from: http://www.reasonablefaith.org/Is-Molinism-as-Depressing-as-Calvinism.

Edwards J (1957a) Freedom of the Will. In Ramsey P (ed) Works of Jonathan Edwards, volume 1. New Haven, CT: Yale University Press.

Edwards J (1957b) Original Sin. In Holbrook CA (ed) Works of Jonathan Edwards, volume 3. New Haven, CT: Yale University Press.

Feinberg J (2001) No One Else Like Him. Wheaton, IL: Crossway.

Gerstner J (1992) The Rational Biblical Theology of Jonathan Edwards, volume 2. Orlando, FA: Ligonier.

Helm P (1994) The Providence of God. Downers Grove, IL: InterVarsity.

Keathley K (2010) Salvation and Sovereignty: A Molinist Approach. Nashville, TN: B \& H Academic.

McGregor Wright RK (1996) No Place for Sovereignty: What's Wrong with Freewill Theism. Downers Grove, IL: InterVarsity.

Moreland JP (2002) Miracles, Agency, and Theistic Science: A Reply to Steven B. Cowan. Philosophia Christi 4(1): 139-160.

Olson R (2006) Arminian Theology: Myths and Realities. Downers Grove, IL: InterVarsity.

Picirilli R (2002) Grace, Faith, and Free Will. Nashville, TN: Randall House. 
Piper J (1998) God's Passion for His Glory: Living the Vision of Jonathan Edwards. Wheaton, IL: Crossway.

Saucy R (1993) Theology of Human Nature. In Moreland JP and Ciocchi DM (eds) Christian Perspectives on Being Human: A Multidisciplinary Approach to Integration. Grand Rapids, IL: Baker, pp. 17-52.

Sproul Jr RC (1999) Almighty over All: Understanding the Sovereignty of God. Grand Rapids, IL: Baker.

Sproul Sr RC (1986) Chosen by God. Wheaton, IL: Tyndale House.

Walls J (1990) Is Molinism as Bad as Calvinism? Faith and Philosophy 7(1): 8598.

Ware B (2004) God's Greater Glory: The Exalted God of Scripture and the Christian Faith. Wheaton, IL: Crossway.

Welty G (2016) Molinist Gunslingers: God and the Authorship of Sin. In Alexander D and Johnson DM (eds) Calvinism and the Problem of Evil. Eugene, OR: Pickwick, pp. 56-77.

Wright R (1994) The Moral Animal: The New Science of Evolutionary Psychology. New York, NY: Vintage. 